\title{
Evaluating the Role of Media in Implementation of $85 \%$ Graphic Warnings on Tobacco Products in India
}

\begin{abstract}
Background: In common with many countries globally, India has a history of graphic health warnings (GHWs) being weakened or delayed due to tobacco industry influence. If tobacco is eliminated from society, nearly $30 \%$ of all cancers can be prevented. Objectives: This study examines the role of the media in the recent changes to the $85 \%$ GHWs implementation in India. Materials and Methods: Media articles from the date of notification of $85 \%$ GHW (October 15, 2014) to the date of its implementation (April 1, 2016) were collected and coded as pro, anti, or neutral. These were compared, correlated to significant government actions during the time period to determine if media influenced the government actions on the implementation of GHWs. Results: A total of 3301 media articles regarding $85 \%$ GHWs were found during the study period, of which 2961 were pro, 333 were anti, and seven were neutral. The results showed that there was a positive correlation of media on the implementation of GHWs. Conclusion: Media coverage of the issue did appear to have an impact.
\end{abstract}

Keywords: Cancer, graphic health warnings, India, pictorial pack warnings, tobacco

\section{Introduction}

Graphic warnings on tobacco products are one of the most effective policies to prevent tobacco use initiation, particularly for illiterate population. ${ }^{[1]}$ The Global Adult Tobacco Survey 2017 showed that $28.6 \%$ of people aged 15+ consume tobacco in India. ${ }^{[2,3]}$ There is substantial global evidence which demonstrates that large graphic health warnings (GHW) are a cost-effective method to communicate the health risks. ${ }^{[4-6]}$

Globally, delays in the implementation of GHWs are common. The first GHWs were introduced in Iceland in 1985. Aware of their effectiveness, the tobacco industry (TI) launched a global strategy which successfully prevented their introduction until 2000, when Canada became the second country to introduce them. ${ }^{[7]}$ In Canada and other countries that followed such as Brazil and Australia, there were significant delays. ${ }^{[8]}$ Implementation has continued to be a challenge due to TI opposition, especially in low- and middle-income countries such as India. ${ }^{[9,10]}$

GHWs covered $40 \%$ of the front panel of tobacco products in India from 2008. ${ }^{[1]}$

\footnotetext{
This is an open access journal, and articles are distributed under the terms of the Creative Commons Attribution-NonCommercial-ShareAlike 4.0 License, which allows others to remix, tweak, and build upon the work non-commercially, as long as appropriate credit is given and the new creations are licensed under the identical terms.
}

For reprints contact: WKHLRPMedknow_reprints@wolterskluwer.com
On October 15, 2014, the Indian Ministry of Health and Family Welfare (MoHFW) amended the 2008 Packaging and Labeling Rules to increase the GHW size on all tobacco products to $85 \%,{ }^{[12]}$ a decision which would see India ranked third globally in terms of size warnings. ${ }^{[13]}$ The amendment was due to come into effect from April 1, 2015. However, on March 31,2015 , it was stalled indefinitely at the behest of a Parliamentary Committee, ostensibly to allow further discussion with stakeholders. ${ }^{[11]}$ The amendment was finally implemented on April 1, 2016. ${ }^{[12]}$ Between promulgation and eventual implementation, the issue was covered widely by media, with many groups, both in favor of and against the new rules, involved in the debate and quoted by media. Stakeholders included central and state governments, activists, doctors' associations, farmers' groups, trade and industry associations, and the parliament.

Legal action was also taken by the industry, which filed cases in various state high courts (HCs). Support from media or lack, thereof, can have a significant influence on government actions. ${ }^{[14]}$ Within the Indian public health community, it is widely

How to cite this article: Sarin A, Chaturvedi P,
Mehrotra R, Ranjan P, Seth S, Janardhanan R.
Evaluating the role of media in implementation of $85 \%$
graphic warnings on tobacco products in India. Indian
J Med Paediatr Oncol $2020 ; 41: 879-84$.

How to cite this article: Sarin $A$, Chaturvedi $P$, Mehrotra R, Ranjan P, Seth S, Janardhanan R. graphic warnings on tobacco products in India. Indian J Med Paediatr Oncol 2020;41:879-84.

\section{Ashima Sarin ${ }^{1,2}$, Pankaj Chaturvedi ${ }^{3}$, Ravi Mehrotra ${ }^{4}$, Priya Ranjan ${ }^{5}$, Sanjay Seth ${ }^{2}$, Rajiv Janardhanan ${ }^{1}$}

${ }^{1}$ Amity Institute of Public Health, Amity University, Noida, Uttar Pradesh, India, ${ }^{2}$ Department of Public Health, Sambandh Health Foundation, Gurgaon, Haryana, India, ${ }^{3}$ Department of Head and Neck Surgery, Tata Memorial Hospital, Mumbai, Maharashtra, India, ${ }^{4}$ India Cancer Research Consortium, ICMR-DHR, New Delhi, India, ${ }^{5}$ Department of Electronics and Communication Engineering, SRM University, Amravati, Andhra Pradesh, India

Submitted: 29-Jul-2020 Revised: 18 -Sep-2020 Accepted: 04-Oct-2020 Published: 31-Dec-2020

Address for correspondence: Ms. Ashima Sarin, Coral 309, Ourania, Golf Course Road, DLF Phase 5, Sector 53, Gurugram - 122 002, Haryana, India. E-mail: ashima.sarin@ sambandhhealth.org

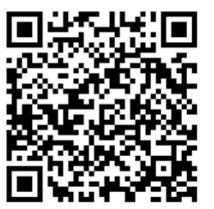


believed that media plays a role in policy-making. ${ }^{[15]}$ However, to date, there has been no data-driven study on the role of the media in tobacco control policy-making. This research paper analyzes print and online media coverage and government action for and against the larger health warnings for the period between the day new rule was announced (October 15, 2014) and the day it came into effect (April 1, 2016), i.e., implementation.

\section{Materials and Methods}

The articles were collected through public relations (PR) agency "Comma Communications Management," which tracked daily news related to tobacco within India on many tobacco-related issues such as advertising, promotion, pack labelling and warnings, Goods and Services Tax, and Illicit trade between October 15, 2014 and April 4, 2016.

In the present study, selected cities representative of national picture of tobacco consumption, the PR agency collected news daily from all papers and online 10 states and 1 Union Territory of India (Andhra Pradesh, Assam, Bihar, Chandigarh, Delhi, Karnataka, Kerala, Maharashtra, Rajasthan, Tamil Nadu, and Uttar Pradesh) on the issue of tobacco.

The articles of the English language were considered for the study. These articles were manually screened on the issue of $85 \%$ GHWs, which included tobacco-related news articles on policy, from all newspapers, online media daily, and all clips on GHWs from daily E-mails (n-507). Study also included major news agency articles on the issue of $85 \%$ graphic warnings through Press Trust of India, United News of India, Indo-Asian News Service, and Asian News International. ${ }^{[16]}$

Media articles E-mails from Comma were entered in Microsoft Excel sheet by date with headlines, page number, edition, newspaper/media outlet name, and the classification of the article as in favor of pro, against anti, or neutral [Table 1].

Key government events were also identified through the news media reports. Government events are actions by the government, defined such as there was a policy notification, policy on hold, formation of committee on subordinate legislation (CoSL), etc. Each event was coded as pro or anti-based on whether it was likely to progress or delay implementation. The classification of articles and government events were cross-checked by a second researcher to remove bias.
The number of pro- $85 \%$ and anti- $85 \%$ media articles were displayed graphically over time together with government events to enable a visual examination of the temporal relationship between media and government events. Correlation was performed using the Pearson correlation test to see if media influenced government events. Further, it was seen if it was opposite as government events led to media articles.

\section{Statistical analysis}

Descriptive analysis was performed. Normal distribution of the values was tested using the Kolmogorov-Smirnov test. The dependent variable coded as (government events occurred during study period $=1$ and no government events $=0$ ) and independent variable coded as (media occurred during study period $=1$ and no media $=0$ ).

The results for these scales were reported as proportions events (including media and government). Comparison between the government events occurred during the study period and media articles published was assessed by the use of Chi-squared test with Pearson's Chi-square test. Normality was assessed for government events and media articles.

Media articles published associate factors were analyzed in univariate logistic regression, using government events occurred during study period as outcome variables. $P \leq 0.05$ in a two-tailed test was considered statistically significant. Statistical analyses were performed using the SPSS (the Statistical Package for the Social Sciences) IBM Corp. Released 2017. IBM SPSS Statistics for Windows, Version 25.0, IBM Corp., Armonk, NY, USA.

Logistic regression was done using the dependent variable coded as (government pro events occurred during study period $=2$, government anti-events occurred during study period $=1$, and no government events occurred during study period $=0$ ), and independent variable coded as (media proactions occurred during study period $=2$, media anti-actions occurred during study period $=1$, and no media occurred during study period $=0$ ). Comparison between government events occurred during the study period and media articles published was assessed using the Chi-square test with Pearson's Chi-square test.

Media articles published associate factor was analyzed in a univariate logistic regression, using government actions occurred during the study period was outcome variable (for logistic regression both pro-and anti-events merged).

\begin{tabular}{lll}
\hline & Table 1: Media articles classification criteria & \\
\hline Pro article & Anti-article & Neutral article \\
\hline Included statements/viewpoints in favour of & Included statements/arguments/viewpoints anti & Included balance of pro and anti-statements/ \\
$85 \%$ GHWs & $85 \%$ GHWs & viewpoints/arguments \\
Typically from public health community & Typically from tobacco industry, Ministers/ & Typically from tobacco control and tobacco \\
and/or supportive Government Ministers & Members of Parliament anti 85\% & industry statements \\
\hline
\end{tabular}

GHWs - Graphic health warnings 


\section{Results}

A total of 3301 articles were published from October 15, 2014 (promulgation) to April 4, 2016 (implementation). From these, 1164 were original articles and 2137 were syndicated.

Nearly $90 \%(n=2961)$ of the articles were coded as pro, with $10 \%(n=333)$ coded as anti. Only seven neutral articles were published during the study [Figure 1].

In the implementation of the $85 \%$ graphic warnings, both the pro and anti-forces were the most active during March 2016. All syndicated articles were pro, and most were

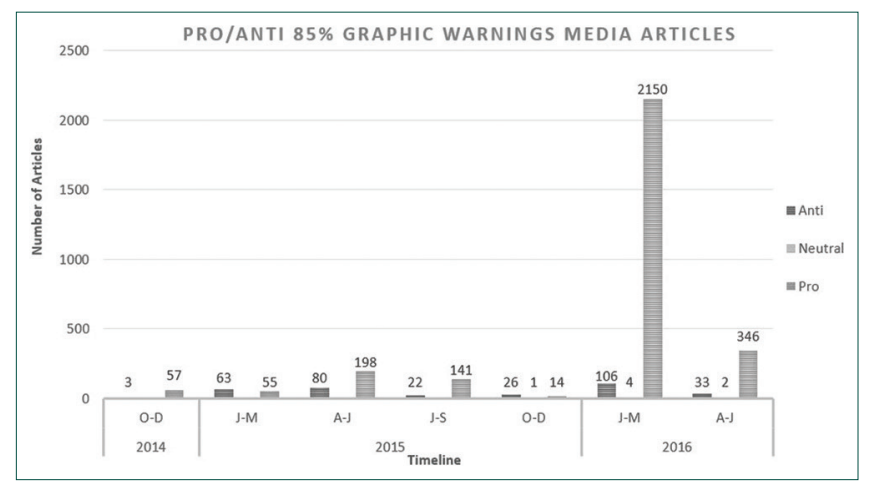

Figure 1: Media articles classification and volume immediately before and after the actual implementation date of April 1, 2016. Syndicated articles were captured at three intervals of time: June-September 2015 62/141, January-March $2016 \quad 1823 / 2150$ and April-June 2016 252/346 syndicated articles. The majority of April-June 2016 articles were published in the first 4 days of April [Table 2 and Figure 2].

Table 2 and Figure 2 provide the interaction between media coverage and government events.

In 2015 week 8, the TI protested that the rules for $85 \%$ GHW are not practical to implement, shown in the graph as negative media coverage. In response, the health minister (HM) issued a statement (government event 2) defending the notification. This was the first major statement on this issue by the new Union Health Minister, who had been appointed in November 2014.

In 2015 week 11, the CoSL raised the GHW matter and wrote to the MoHFW to put a hold on the $85 \%$ GHW and the MoHFW did so on March 23, (government events 3 and 4), even though the HM reiterated his support for the new GHWs shortly after the implementation delay was announced (Government event 5). This generated significant anti $85 \%$ media which peaked around 2015 week 13. In response, both the HM and Prime Minister

\begin{tabular}{|c|c|c|c|}
\hline \multicolumn{4}{|c|}{$\begin{aligned} \text { Table 2: Government actions/events } \\
\end{aligned}$} \\
\hline S.No. & Date & Government actions/events & Pro/anti \\
\hline 1 & 15-Oct-14 & Notification of $85 \% \mathrm{PW}$ & Pro event \\
\hline 2 & 25-Feb-15 & Union Health Minister gave a statement in media in favour of the Graphic Warnings & Pro event \\
\hline 3 & 18-Mar-15 & $\begin{array}{l}\text { Committee on Subordinate Legislation [a Parliamentary Committee wrote to the Health } \\
\text { Ministry to hold large GHWs] }\end{array}$ & Anti-event \\
\hline 4 & 23-Mar-15 & Graphic Warnings put on hold & Anti-event \\
\hline 5 & 25-Mar-15 & Union Health Minister made a statement in favour of $85 \%$ graphic warnings & Pro event \\
\hline 6 & 03-Apr-15 & Union Health Minister made a statement in favour of $85 \%$ graphic warnings & Pro event \\
\hline 7 & 05-Apr-15 & $\begin{array}{l}\text { Statement by the Prime Minister of India on graphic warnings [Prime Minister is running } \\
\text { the Nation, hence, an assurance that this will be implemented] }\end{array}$ & Pro event \\
\hline 8 & 01-May-15 & $\begin{array}{l}\text { Union Finance Minister made a statement that Govt supports graphic warnings [Second- } \\
\text { most powerful Minister in the country] }\end{array}$ & Pro event \\
\hline 9 & 16-Jul-15 & $\begin{array}{l}\text { Delay Strategy: Committee on Subordinate Legislation (CoSL) asked to meet with Civil } \\
\text { societies for implementation of } 85 \% \text { graphic warnings }\end{array}$ & Anti-event \\
\hline 10 & 19-Aug-15 & $\begin{array}{l}\text { Union Health Minister maintains status quo on } 85 \% \text { graphic warnings [Health Ministry } \\
\text { maintains status quo on GHW] }\end{array}$ & Anti-event \\
\hline 11 & 27-Aug-15 & $\begin{array}{l}\text { Affidavit submitted to the Rajasthan High Court asking for 6-months extension. [Delay } \\
\text { from the Government] }\end{array}$ & Anti-event \\
\hline 12 & 10-Sep-15 & CoSL (Parliamentary Committee) gave report to hold GHW & Anti-event \\
\hline 13 & 25-Sep-15 & Graphic Warnings to be implemented on $1^{\text {st }}$ April 2016 & Pro event \\
\hline 14 & 18-Dec-15 & CoSL (Parliamentary Committee) seeks clarification on $85 \%$ GHW from Health Ministry & Anti-event \\
\hline 15 & 08-Jan-16 & CoSL seeks clarification on $85 \%$ GHW from Health Ministry & Anti-event \\
\hline 16 & 19-Feb-16 & $\begin{array}{l}\text { Union Health Ministry issued public notice about } 85 \% \text { Graphic Warnings } \\
\text { implementation from April 1, } 2016\end{array}$ & Pro event \\
\hline 17 & 11-Mar-16 & CoSL members deny $85 \%$ GHW stating that it is too harsh for tobacco industry & Anti-event \\
\hline 18 & 16-Mar-16 & $\begin{array}{l}\text { Union Health Ministry made a statement that it will not change the course of warnings } \\
\text { and will stick to the large GHWs }\end{array}$ & Pro event \\
\hline 19 & 01-Apr-16 & Graphic Warnings implemented from $1^{\text {st }}$ April 2016 & Pro event \\
\hline
\end{tabular}

CoSL - Committee on subordinate legislation; GHWs-Graphic health warnings 


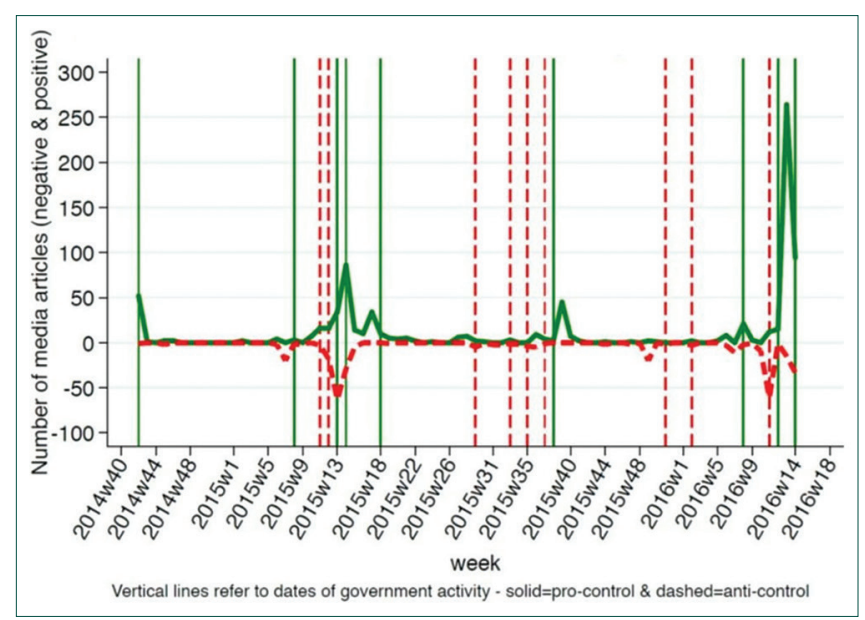

Figure 2: Timeline and government events

(PM) made statements (on April 3 and 5, respectively; Government events 6 and 7) pro 85\% GHW.

During the period from 2015 week 14 to 2015 week 18, after May 1, the Union Finance Minister, made a statement pro $85 \%$ GHW (government event 8). Statements from PM and FM can be seen as the indicators of policy thinking.

In 2015 week 27, the Rajasthan HC gave an order for $85 \%$ GHWs implementation, which put pressure on the MoHFW, as not doing so would place the government in contempt.

In 2015 week29, the CoSL asked to meet civil societies (government event 9), widely considered by the Indian public health community as a delay tactic.

In 2015 week 31, the Rajasthan HC asked the government why it should not issue contempt for not implementing $85 \%$ GHWs. During this time, the TI was filing cases in various state $\mathrm{HCs}$ in the country trying to stall the new GHWs. However, the Rajasthan $\mathrm{HC}$ hearings indicate that it was the Rajasthan HC's "contempt" warning, which seems to have had an influence on government event.

In 2015 week 34, the MoHFW issued statement that the scheduled implementation may be delayed (government event 10) and the MoHFW filed an affidavit with the Rajasthan $\mathrm{HC}$ seeking a 6-month extension for implementation (government event 11). This was seen as a setback and potentially indicated "behind the scenes" action by the TI.

2015 week 37: A known TI person (bidi baron) being re-nominated to this CoSL was seen as a big threat to the legislation by pro $85 \%$ stakeholders. The fact that a bidi baron was on this powerful committee was being called "Tobacco Gate" in the media. Also, in 2015 week37, there was significant pro $85 \%$ media reporting of the WHO's criticism of India's stand on this issue. However, the fears of the pro $85 \%$ forces were realized when the CoSL gave a report to the Government to hold the new GHWs (government event 12).
2015 week 38: The government issued a public notice (government event 13) that the new GHWs would be implemented from April 1, 2016. This legal notice was seen as a firm step in the implementation process.

In 2015 week 44, the TI stepped up its efforts to derail the new GHWs by bringing farmers into the equation and the Federation of All India Farmer Associations launched a major campaign in the national capital protesting the new GHWs.

2015 week 51 and 2016 week 1: The CoSL formally sought clarification from the Health Ministry on GHWs December 18, 2015 and January 8, 2016 (government event 14 and 15). These were seen by the public health community as delay tactics.

2016 week 6: The TI took further steps by getting the bidi manufacturers to go on strike for 10 days in protest.

2016 week 7: The Government of India re-iterated their intentions by issuing another public notice widely covered by media that new GHWs would be implemented from April 1, 2016.

2016 week 10: Perhaps, sensing that the tide was turning, the CoSL and members of parliament against $85 \% \mathrm{GHW}$ gave many press statements, including a plea to reduce the size of GHWs. This led to another formal protest by the CoSL (government event 17).

2016 week 11: The Government emphasized its commitment to $85 \%$ GHWs (government event 18).

2016 week 11: Onwards, nearing the delayed implementation date, the public health community and other supporters, supported the warnings with various activities, whereas the tobacco farmers against it because their livelihood is in danger. As a result, there was a surge of media coverage, both pro and anti.

The implementation date was April 1, 2016 (government event 19), however, that implementation was confirmed only around April 4, 2016, when the stocks of tobacco products with the new GHWs were seen in the market. This coincided with the majority of the media coverage for the period April-June 2016.

It is evident that while some of the media coverage was just reporting of events, many of the press releases caused reactions by the government and the opposing forces.

Correlation outcome shows the relationship between net media articles published and government events was evident that media had a weak impact on the implementation of the $85 \%$ GHWs policy with $\mathrm{R}$ value is 0.1385 [Figure 3].

Media coverage is $92 \%$ times less likely to have government events occurred during the study period (odds ratio $0.08,95 \%$ confidence interval $0.04-0.19$ ). Thus, 


\begin{tabular}{|c|c|c|}
\hline & Table 3: Association be & \\
\hline & Gov & me \\
\hline & Category of events & $\mathrm{N}$ \\
\hline Media events occurred during & No event & \\
\hline study period & Pro event & \\
\hline & Anti-event & \\
\hline Result Details \& Calculation & Key & \\
\hline$x$ Values & $x: x$ Values & \\
\hline$\sum=102$ & r:Y Y Values & \\
\hline $\begin{array}{l}\text { Mean }=0.342 \\
\sum\left(X-M_{x}\right)^{2}=S S_{x}=1229.087\end{array}$ & $\begin{array}{l}M_{x_{x}} \text { Mean of XValues } \\
M_{\dot{x}} \text { Mean of Y Values }\end{array}$ & \\
\hline & $X-M_{x} \& Y-M_{y}$ D Deviation scores & \\
\hline $\begin{array}{l}Y \text { Values } \\
\Gamma=118\end{array}$ & $\left(X-M_{X}\right)^{2} \&\left(Y-M_{y}\right)^{2}:$ Deviation Squared & \\
\hline Mean $=0.396$ & $\left(X-M_{x}\right)\left(Y-M_{y}\right):$ Product of Deviation Scores & \\
\hline$\Sigma\left(\gamma-\mathrm{M}_{\mathrm{y}}\right)^{2}=\mathrm{SS}_{\mathrm{y}}=4607.275$ & & \\
\hline $\begin{array}{l}X \text { and } Y \text { Combined } \\
N=298\end{array}$ & & \\
\hline$\sum\left(X-M_{x}\right)\left(Y-M_{y}\right)=329.611$ & & \\
\hline$R$ Calculation & & \\
\hline$r=\Sigma\left(\left(x-M_{y}\right)\left(Y-M_{x}\right)\right) / v\left(\left(S S_{x}\right)\left(S S_{y}\right)\right)$ & & \\
\hline $\begin{array}{l}r=329.611 / N((1229.087)(4607.275))= \\
0.1385\end{array}$ & & \\
\hline $\begin{array}{l}\text { Meta Numerics (cross-check) } \\
r=0.1385\end{array}$ & & \\
\hline The value of $R$ is 0.1385 . & & 1 \\
\hline
\end{tabular}

Figure 3: Correlation media and government event

media is less likely to influence government events. We also studied the impact of government events on media articles. On regression analysis, government events leading to media articles were present in $43.9 \%$ of the cases. Thus, suggesting that media acts as an instrument to inform public in the times when the government events were on rise [Table 3].

\section{Discussion}

Tobacco consumption is an epidemic globally. It accounts for $30 \%$ of all cancer deaths. ${ }^{[17]}$ There is an immediate need to reduce the prevalence and large GHWs in India witnessed a delay of 12 months from the scheduled to actual implementation. This study shows that there was significant uncertainty about policy implementation of $85 \%$ GHWs until it was finally implemented on April 1, 2016. Pro $85 \%$ media articles outnumbered anti $85 \%$ articles, showing that pro camp managed more media attention; however, this coverage often occurred after positive government events rather than before.

There was concern among the tobacco control activists that the TI was engaging in "behind the scenes" lobbying outside the glare of media attention. ${ }^{[18]}$ Our data supports this theory, particularly given the range of government events to delay the policy, which often occurred in the absence of media coverage supportive of the anti-position. Our analysis also shows that media occurred after pro Government event, thus showing its influence on media. It is possible that the level of pro media coverage limited the extent to which "behind the scenes" lobbying by the TI was able to exert influence.

The most important role played in GHWs was by the Rajasthan $\mathrm{HC}$, which had ordered immediate implementation but this event did not receive optimal media coverage to have much impact on the government. Future media strategies should ensure that legal rulings, particularly those that support tobacco control legislation, are given prominence. There is a scope for media to pick up pro government events more effectively.

It is clear that media was not the only factor influencing this policy implementation. It was reporting government events, moves by the tobacco control activists, those by the TI and also the legal action on the matter. We found that there was a considerable impact of government event on media response. It meant that media took the responsibility to inform the public about the government events related to this issue. Thus, creating awareness and keeping the public updated about this topic. Our results have questioned the impact of media on government tobacco policy implementation. There is limit to which media creates a significant impact, thus, other influential factors directing tobacco policy implementation needs to be explored. Research to obtain the views of policy-makers and bureaucrats would be a useful area for future exploration.

\section{Limitation}

Regional language articles may have been excluded from the sample as the data were limited to ten states of India.

\section{Conclusion}

Media plays an important role in informing public about the government policies and must be involved right from promulgation to implementation of policies, thus forming public opinion.

\section{Acknowledgments}

The authors would like to thank the CTFK, Achyutha Gadde, Dr PC Gupta, Pranshu Rana, Akshay Patil, Annu Sharma. The conclusions and recommendations are those of authors and do not represent the views of any organization.

\section{Financial support and sponsorship}

Nil.

\section{Conflicts of interest}

There are no conflicts of interest. 


\section{References}

1. Rahman MM, Arif MT, Abd RM, Suhaili MR, Tambi Z, Akoi C, et al. Effectiveness of pictorial health warning on cigarette packages: A cross-sectional study in Sarawak, Malaysia. Malays Fam Physician 2015;10:19-26.

2. World Health Organization Global Adult Tobacco Survey 2017, Ministry of Health \& FamilyWelfare. Available from: https://www. who.int/tobacco/surveillance/survey/gats/GATS_India_2016-17 FactSheet.pdf?ua=1. [Last acessed on 2019 Mar 01].

3. Patel DR. Smoking and Children. Indian J Pediatr 1999;66:817-24.

4. Monárrez-Espino J, Liu B, Greiner F, Bremberg S, Galanti R. Systematic review of the effect of pictorial warnings on cigarette packages in smoking behavior. Am J Public Health 2014;104:e11-30.

5. TC Project. Pictorial Health Warnings in India: Why Larger Warnings Should be Implemented Without Delay. ITC Fact Sheet \#1 2015. University of Waterloo, Waterloo, Ontario, Canada. Available from: https://itcproject.org/files/India_WL_Fact_Sheet Draft-May26-FINAL-V2.pdf. [Last accessed on 2019 Feb 27].

6. World Health Organization. Conference of the Parties to the WHO FCTC, Guidelines for Implementation of Article 11 of the WHO Framework Convention on Tobacco Control (Packaging and labelling of tobacco products). World Health Organization; 2008. Available from: https://www.who.int/fctc/guidelines/ adopted/article_11/en/. [Last accessed on 2019 Mar 06].

7. Hiilamo H, Crosbie E, Glantz SA. The evolution of health warning labels on cigarette packs: The role of precedents, and tobacco industry strategies to block diffusion. Tob Control 2014;23:e2.

8. Miller, CL, Hill, D, Quester PG, Hiller, JE Response of mass media, tobacco industry and smokers to the introduction of graphic cigarette pack warnings in Australia. Europ J Public Health 2009;19:644-9.

9. Oswal KC, Pednekar MS, Gupta PC Tobacco industry interference for pictorial warnings. Indian J Cancer 2010;47 Suppl 1:101-4.

10. Gilmore AB, Fooks G, Drope J, Bialous SA, Jackson RR. Exposing and addressing tobacco industry conduct in low-income and middle-income countries. Lancet 2015;385:1029-43.

11. Sarin A, Janardhanan R. India: The long road to $85 \%$ tobacco pack warnings. BMJ Tobacco Control News Analysis 2017;26:362-63.

12. Ministry of Health and Family Welfare, Government of India, the Cigarettes and Other Tobacco Products (Packaging and Labelling) Amendment Rules; 2014. Available from: http:// www.tobaccolabels.ca/wp/wp-content/uploads/2014/11/ India-2014-Cigarettes-and-other-Tobacco-Products-AmendmentRules1.pdf. [Last accessed on 2019 Mar 04].

13. Cigarette Package Health Warnings, Canadian Cancer Society; October, 2016. Available from: http://www.tobaccolabels.ca/ wp/wp-content/uploads/2016/11/Cigarette-Package-HealthWarnings-International-Status-Report-English-CCS-Oct-2016. pdf. [Last accessed on 2019 Mar 05].

14. Understanding Media and Culture: An Introduction to Mass Communication; 2016. Available from: https://open.lib.umn.edu/media and culture/ chapter/15-7-media-influence-on-laws-and-government/. [Last accessed 2019 Dec 25].

15. Ashraf P. The role of media in good governance: Paid news culture of media and the challenges to Indian democracy. Int Res J Soc Sci 2014;3:41-3.

16. News Agency Journalism. Available from: https://www.britannica. com/topic/news-agency. [Last accessed on 2020 Jan 18].

17. Anand P, Kunnumakara AB, Sundaram C, Harikumar KB, Tharakan ST, Lai OS, et al. Cancer is a preventable disease that requires major lifestyle changes. Pharm Res 2008;25:2097-116.

18. The Indian Express. Available from: https://indianexpress.com/ article/explained/supreme-court-tobacco-packet-warning-tobaccopictorial-warnings-2791062/. [Last accessed on 2019 Mar 07]. 